\title{
Towards active utilisation of community forestry: Silvo-institutional model for sustainable forest management in Nepal
}

\author{
N. S. Paudel ${ }^{1 *}$, H. Ojha ${ }^{2}$, K. Shrestha ${ }^{2}$, E. Cedamon ${ }^{3}$, R. Karki ${ }^{1}$, G. Paudel ${ }^{1}$, \\ M. Basyal ${ }^{1}$, I. Nuberg ${ }^{3}$ and S. Dangal ${ }^{4}$
}

This paper explains what we term the 'silvo-institutional model' for a more productive, sustainable and equitable management of community forests in Nepal. The paper draws on four years of action research in six research sites of Kavre and Lamjung districts, complemented by the review of silviculture-based forest management by Government of Nepal in various parts of the country. The findings indicate that first, early silviculture-based forest management initiatives have failed because they did not adequately consider the policy and institutional dimensions. Second, current initiatives, while looked promising for the active utilisation of community forests, have faced with complex regulatory and institutional barriers. We argue that a new 'silvoinstitutional model', which combines technological and institutional dimensions, has a potential to increase the prospect of successful implementation of silviculture-based forest management.

Key words: Community forestry, forest management, institutions, Nepal, policies, silviculture, silvo-institutional model

$\mathrm{T}$ community forests are not actively managed and its potential has not been realised despite growing need for timber and other forestry products (Yadav et al., 2009; Thoms, 2008). In Nepal, with about $45 \%$ of forest in the country, it's strongly argued that forest has potential to contribute to local livelihoods and national economy. However, studies have shown that Nepal's forests have not provided economic benefits to its full potential (Subedi et al., 2014; Thoms, 2008). The central reason is that there is little or no management of these forests based on adopting silvicultural principles (Paudel et al., 2014; Subedi, 2012; Yadav et al., 2008; Springate-Baginski et al., 2003). The question is then why these forests remain not actively managed, what are the causes and consequences and how these forests can be better managed. The paper explains one of the attempts we made as part of an action research project ${ }^{5}$ which tested what we term 'silvo-institutional model' (SIM) as a potential strategy to catalyse active management of community forests in the hills of Nepal.

In the past, the Government of Nepal (GoN) has made several attempts to manage its forests through employing silviculture-based interventions. However, most of these initiatives were either not implemented at all, or when implemented, failed to achieve stated objectives mainly because of weak political will, low institutional capacity and poor governance. Currently, the government is piloting an initiative within the brand of "scientific forestry". Although the government is keen to scale out the piloting programme, there are serious oppositions to scientific forestry on the grounds of inadequate consideration of institutional aspects. Therefore, it is important to analyse the previous efforts as well as review the current initiatives so as to identify and understand key issues, explore possible solutions to these issues and support active forest management through silviculturebased sustainable forest management practices for materialising economic potential along with social and environmental benefits.

${ }^{1}$ Forest Action, Nepal. *E-mail: nspaudel@gmail.com

${ }^{2}$ University of New South Wales, Australia

${ }^{3}$ University of Adelaide, Australia

${ }^{4}$ RECOFTC, Nepal

${ }^{5}$ The action research project was implemented during five years period in 2013-2018 in Kavre and Lamjung. The primary objective of the project is to enhance livelihood and food security from Agroforestry and Community Forestry in the mid-hills of Nepal. 
This paper investigates key governance and institutional elements of silviculture-based forest management practices in Nepal's community forestry. In doingso, it will seek to answer the following questions surrounding silvicultural interventions in community forestry. What are the historical attempts to introduce silviculture in Nepal's forest management? How successful were those interventions? How can technical aspects of silviculture be combined with institutional aspects of decision making and implementation? What can SIM offer in realising the benefits of forest management by the local communities? Before presenting the SIM, we reviewed past attempts of active forest management in Nepal. We then analysed the challenges of active forest management in the two case study districts. Then we analysed the cases to present the SIM in our discussion and conclusion.

\section{Quest for active forest management: a historical overview}

Despite about $45 \%$ of the country's area under forests, the contribution of the forest sector to local and national economy has remained much less than the potential in Nepal (Chhetri et al., 2012; Banjade et al., 2011; Thoms, 2008). As the national mood have switched towards active forest management through developing and scaling out silviculture innovations, several attempts for active forest management have been made. These have stimulated debates in scientific forest management, though outcomes on the ground have remained limited. A case from the piloting attempt in Bara forest, in Terai region by Enso, a Finish company in 1996 reveals some interesting insights. The piloting was to introduce a modern sustainable forest management in Nepal and boost local and national economy. However, it triggered widespread opposition. Federation of Community Forestry Users Nepal (FECOFUN) and many civil society organisations launched protest campaigns across the country against the pilot project arguing that the project would convert the natural Sal forests into a barren land due to poor regeneration plan. The protesters also argued that the pilot failed to recognise the interdependencies of local communities, local livelihoods and forests. When a stakeholder consultation was conducted, it appeared that Community-Based Organisations (CBOs) and many local political representatives were against bringing the foreign company to manage forests.
The forest officials in Kathmandu were divided as some mentioned that rather the government should manage the forest, not by a foreign company. Finally, the pilot project ended as Enso gave up the project (Hurtig, 1998).

Operational Forest Management Plan (OFMP) proposed for 17 Terai districts in 1996 is another case of failure in an attempt to manage the forest more actively. While, these were good technical plans to manage the Terai forests, these plans remained only in the paper. They did not go ahead due to lack of adequate financial resources to implement the plan, together with problems coming from the opposition of local communities and lack of political will from the government. Little engagement with local communities and stakeholders resulted in a widespread opposition from FEOCFUN and CBOs. Many District Forest Offices (DFOs) were not aware of the plans which were prepared by the project's hired consultants. DFOs were largely excluded in the process. Consequently, DFOs were not sure about technical as well as administrative and financial details of the plans. Therefore, DFOs were not prepared to implement the plan. Technical quality of the plans seemed to be poor, while DFO's capacity to implement the plan remained weak. Most importantly, there was lack of financial resources to implement the plan. Neither the donor, who supported the planning process, nor the GoN provided funding or commitment to implement the programme at a larger scale. Consequently, these plans remained only in paper.

Another interesting example is the Sagarnath Forestry Development Project, which originally covered about 10,000 ha of prime Sal forest in Nepal's central Terai region, initially started with support from Asian Development Bank (ADB) and Oil Producing and Exporting Countries (OPEC) in 1978. The project shows challenges with governance and institutional aspects of active forest management in Nepal. The project was intended to increase supply of fuelwood to Kathmandu and other major cities in the context of serious fuelwood crisis of the 1970s. Unfortunately, the project could not go as planned due to three reasons. First, it was driven by outsiders' ideas, funding and technology. As a result, it had no local ownership of the project. Secondly, Forest Products Development Board - a semi government entity - was supposed to function independently outside the everyday 
government functioning. However, it was highly politicized because of the overt influences of politicians and senior bureaucrats in the strategies and functioning of the project. Third, over 3,000 ha of the plantation area was encroached by the landless people and the management of land conflict was a chronic political challenge in this project and beyond, across the Terai.

Based on the above analyses, it is clear that most of these initiatives were promoted by high profile international agencies; they were purely driven by so-called 'objective science', and had sophisticated technical plans. However, these initiatives failed to give due attention required to anticipate, recognise and address governance and institutional aspects,which undermined the objective of those initiatives. Engagement with local actors remained limited, while it is most critical. In most cases, programmes could not garner needed local support and in some cases these even faced severe opposition. Protest of FECOFUN in Bara case is in point where there was lack of local support in Sagarnath and the absence of political will and institutional capacity of the Department of Forests (DoF) undermined the implementation of those initiatives. The challenges faced by these initiatives provide a strong rationale for the exploration of innovative approach to silviculture-based forest management that integrates technical assessment and planning with institutional process in practice.

\section{Recent initiatives of scientific forestry in Terai}

Silviculture-based forest management, usually referred as 'Scientific Forest Management' has been practiced in collaborative, national and community forests in the Terai. The concept has been slowly rolling out in some of the foothills districts. To direct the process for scientific forest management, a guideline for scientific forest management has been approved by the Ministry of Forests and Soil Conservation (MFSC) in 2015, which details social and technical process in site selection and development of management plans. Though, the guidelines outline a simple social process for site selection, vision and objective mapping, the technical processes have been observed to be too complex among most of the foresters and especially the local communities. The participation of local communities and local level foresters has been a ritual only. This is due to limited understanding on the complex process of management plan development. A handful of foresters have been serving as experts in the development of most of the management plans. This has resulted limited ownership among the government official-foresters and community members at field level.

Ownership of local community and local forest official is crucial for continuation of these initiations. For this, they should involve and or understand all the steps and process. Similarly, knowledge management within the community and government institutions has been critical for sustainability of the initiation. For example, if a person involving in the process is transferred, there will be nobody to undertake the activities as well as very limited information are remained within the institution. To retain institutional memory, mechanism will have to develop at institutional level. Currently, while the technical process of developing management plans and their implementation is progressing fast, there are several gaps in associated institutional elements including governance, capacity and ownership of local institutions in the process.

\section{Silviculture in community forests}

We have closely observed and documented silviculture operation in six research sites in Kavre and Lamjung districts, where forest management operations are strongly linked with deeply rooted institutional challenges. There were problems at all three levels. At the national level, public discourse is heavily influenced by protection oriented forest management. In particular, media, political actors and Commission for the Investigation of Abused of Authority (CIAA) actions were largely restrictive to any improvements in forest management. Policies, laws and regulation were designed accordingly. At the district level, there is no incentive for forest officials to actively promote silviculture in their respective constituencies because of feeling of insecurity and threat to their office that silviculture-based operation might bring. These fears are then passed on to operational plans (OP), harvesting permits, sale and transportation permits. Quite often, officials interpret and adapt the regulatory instruments on their own benefit. At the community level, Community Forest (CF) members are conditioned not to fell trees; there is serious mistrust between different groups within community forest user group (CFUG). 
Silvicultural operation simply adds risks to those CFUGs, which are suffered by poor governance, internal conflicts, and weak institutional capacity. In addition, when the research team first visited the forests, we observed several technical errors related to thinning, pruning, singling and other regular silvicultural activities. In addition to institutional challenges, there is stark gap in technology and skills among the local forest managers.

As reflected in the past attempts of the government, or the widespread challenges in current forest management efforts by the CFUGs, the policy environment and socio-institutional contexts are not very conducive to silviculture. The predominant response to this situation is anything cannot be done unless a favourable policy regulatory environment is established at the centre. However, given the prolonged political transition, frequent changes in the government and the short-term tenure of officials in any particular role indicate that policy environment cannot be changed overnight. At the same time,we cannot wait for getting the policy and institutional environment getting perfect; as they may never be perfect even in the best case scenario. Since the last 21 years of Bara forest case or an attempt in implementation of OFMPs, little change has been seen either in policy and legal framework or in the institutional environment of our forest agency or related other stakeholders. On the other hand, there have been studies showing a huge annual loss from non-management of Nepal's forest (Hill, 1999; Subedi, 2012). In this context, a pragmatic strategy is to explore available windows in policies, laws, institutions through which one expands space and get through. In recent years, at least in the discursive level there has been an increased appreciation of the forest management which will provide forest officials and others a moral support to go ahead.

The above cases show that all past initiatives on silviculture-based forest management have failed to fully implement and achieve their stated outcomes. The cases also show that these initiatives were undermined by poor governance and inadequate considerations of institutional dimensions of active forest management. These include lack of proper engagement with local communities and concerned stakeholders, lack of transparency in the process, weak ownership of the relevant actors, and inadequate financial and other support mechanisms.

\section{Institutional challenges in community forest management in Kavre and Lamjung}

Forest management, particularly timber management, is at the heart of community forestry process. Yet, forest management in CF is seriously undermined by a series of governance and institutional challenges, when one considers the issue of timber management. These include intra CFUGs conflict, lack of trust between the leadership and CFUG members, the delivery of support from DFO, and legal cases at DFO, court or with CIAA. Table 1 presents a few sample cases from Kavre and Lamjung districts that have blocked or seriously hindered timber harvesting, transportation or sale.

Table 1: Governance challenges in community forest management

\begin{tabular}{|c|c|c|}
\hline Sites & Year & Legal case \\
\hline Dharapani & $069 / 70$ & $\begin{array}{l}\text { Financial embezzlement by EC chair, CIAA case, and auctioned tim- } \\
\text { ber could not be sold and fire damaged } 950 \mathrm{cft} \text { of timber later in the year. }\end{array}$ \\
\hline Chappani & $072 / 73$ & $\begin{array}{l}\text { Timber harvested after receiving DFO permit could not be sold. Reconstruction } \\
\text { related circular was cited as a reason. Later } 800 \mathrm{cft} \text { of timber damaged by fire. }\end{array}$ \\
\hline Langdi Hariyali & $073 / 74$ & $\begin{array}{l}\text { Roundwoodweretakentosawmillafterharvestasperthepermit, policeconfiscatedit } \\
\text { andalegalcasewaslaunched.DFOislookingatthecaseatthetimeofwritingthispaper. }\end{array}$ \\
\hline Langdi Hariyali & $071 / 72$ & $\begin{array}{l}\text { Few trees were felled due to Mid-hill Highway construction; the road } \\
\text { authority was much higher and powerful, and therefore, CFUG was } \\
\text { not involved at all in tree felling. Yet, DFO took action against CFUG. } \\
\text { That demoralises forest management enthusiasm and plan of the CFUG. }\end{array}$ \\
\hline Aapchaur & $071 / 72$ & $\begin{array}{l}\text { Difference between Chapan and actual harvest volume lead to a legal case that } \\
\text { delayed release of timber for trade. Damaged timber sold at cheap price. It re- } \\
\text { sulted in conflict between CF members and leaders and also with DFO staff. }\end{array}$ \\
\hline Kalopani & $072 / 73$ & $\begin{array}{l}\text { Despite harvesting permit, CFUG leaders could not harvest trees, as people were yet } \\
\text { to construct houses due to delayed release of grants by the reconstruction authority. }\end{array}$ \\
\hline
\end{tabular}


As shown in Table 1, a range of governance and institutional issues have hampered active forest management initiatives at the local level. In most cases, issues such as poor transparency, embezzlement, lack of trust among CF members and their leaders, and weak institutional capacity of CFUGs in handling are evident. This is particularly visible where there is a potential to earn substantial revenue from the sale of timber. The second types of issues are related to the technical and administrative support from DFO. In many cases, CFUGs are not getting the expected constructive support from DFOs. However, DFO actions have often resulted in loss of timber from fire, financial and physical costs, psychological torture and alienation from being actively involved in forest management. The third types of issues are related to national policies and legal framework such as cases from CIAA, or that of circulars from National Reconstruction Authority.

Most of the studied sites have a good stock of pine forest. There was a massive plantation in the early 1980s by an Australian Forestry project. If one follows the best silviculture advice, these forests must have been harvested by now. Unfortunately, policy, governance and institutional related issues we discussed above have seriously hinder the forest management activities in these forests. This provides a strong rational in exploring innovations that can address these rather subtle issues while advancing silviculture-based forest management initiatives. Below we present how technical and institutional aspects can be integrated through a SIM that we developed in the research sites.

\section{Developing silvo-institutional model through integrating technical science with institutional processes}

In this section, we describe our integrated approach to establishing silviculture demonstration plots in three research sites: two in Kavre and one in Lamjung. This is what we term 'silvo-institutional model' in this paper, in which we have combined technical aspects of resource assessment, establishing demonstration plots, actual felling and timber distribution with the institutional aspects involving various levels of consultation, developing governance safeguards, prepare required documentation and getting the institutional process right. While this is timeconsuming and costly, especially in establishing demonstration plots, it provided a secure, effective and sustainable pathway to silviculturebased sustainable forest management in the respective sites. This approach builds on works that have emphasised integration of science and participation, adaptive and collaborative learning (King et al., 1990; Banjade, 2006; McDougall et al., 2007) and deliberative scientific practice in Nepal's forest management (Ojha et al., 2010).

In many cases, it has spill over effect to neighbouring groups. A summary of step-by-step process is given in figure 1 and detailed stories of the process in the text that follows.

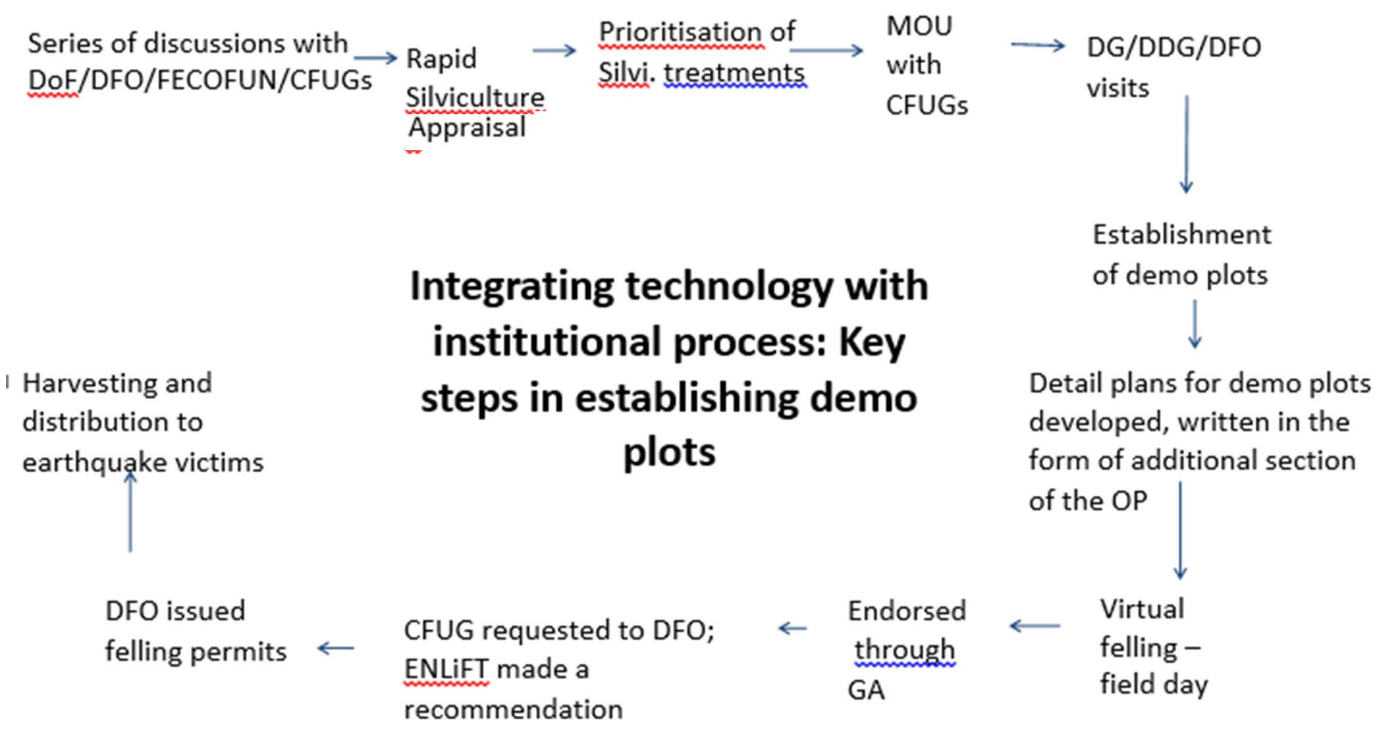

Fig. 1: Process adopted in establishing demo plots in research sites in Kavre and Lamjung 
While the above process provides generic steps taken in all research sites, there were some minor variations in specific sites based on particular socio-ecological characteristics. The above process can be clustered into four broader aspects which are elaborated below:

i) Creating favourable institutional environment: Initially when we started early consultation with the DFO and CFUGs, they indicated a number of risks and expressed feeling insecurity and therefore reluctant to go ahead. We organised a series of informal and formal meetings with DoF officials, DFO staff, FECOFUN and CF leaders. We presented the technical details of how we wanted to proceed, showed the policy and legal windows of secure operation and benefits of taking this initiative. We also organised meetings with media and political leaders in the district and forged meaningful and productive dialogue amongst these actors. These meetings resulted in collective commitment, increased enthusiasm and confidence. These processes provided us a strong but cautious mandate to go ahead with the proposed plan.

ii) Resource assessment and planning: Next we carried out a participatory rapid assessment of the resources, particularly the forest stock, regeneration status and assessed it against the management priorities of the CF members (Cedamon et al., 2016 for details). Gradually, we arrived at preferred management objectives and treatments which were turned into demonstration plots. At the same time, we discussed on the potential threats such as loss of endemic species, fire, wind, grazing, heavy drought, etc. Similarly, we also discussed on the expected inputs and distribution of potential harvest among the $\mathrm{CF}$ members.

iii) Endorsement and approval: While relatively informed CF leaders were involved in the above process, the plans had to be discussed and endorsed by larger mass of CF members. This has political as well as instrumental and mandatory objectives. Accordingly, the plans were presented; feedback and comments were received and adjusted. As the plans were approved along with few comments, these were then finalised and submitted to the respective authorities for approval. Some field visits and small meetings with the $\mathrm{CF}$ members and DFO staff were organised.

iv) Action and monitoring: After the approval, tree felling was carried out, measurements done and products were distributed. A proper documentation was made. The ecological responses (regeneration, etc.) and social responses (responses from CF members, $\mathrm{HHs}$, media) were regularly/periodically monitored. Later on actions were refined based on these responses.

We now bring specific cases, where these principles were experimented with some minor variations based on their particular contexts and needs.

\section{Application of silvo-institutional models: processes and outcomes}

\section{Lampata CFUG, Lamjung}

Lampata CFUG in Madhya Nepal Municipality has 84 ha of mixed Sal (Shorea robusta) forest in lower belt and Chilaune-Katus (SchimaCastanopsis) in upper belt. They used to practice low thinning that neither helped growth of matured trees nor provided required timber to the CF members. CF members were frustrated with low annual harvest volumes of the forest and huge gap between demand and supply. In this context, we established a demonstration plot there.

The establishment of silviculture demonstration plots in Lampata CFUG involved intensive engagement with diverse actors at various levels. After an initial meeting and understanding with the CFUG executive committee (EC), we identified the types of treatments, identified the site for demonstration plot and worked out preparatory work. The chairperson of the EC was assigned with the responsibility to oversee the overall silviculture activities, make arrangements for the harvesting and plantation related activities, including mobilizing user group members in ground preparation, digging the pits, and planting.In addition, the staffs of project entitled, 'Enhancing Livelihoods and Food Security from Agroforestry and Community Forestry in Nepal (EnLiFT)', including a Local Resource Person (LRP), supported CFUGs in seedling supply and plantation. While the labour required for the plantation was managed by the CFUG. 
Fodder trees were planted in rows in the demontration plots which are mostly covered with hill Sal trees. During the three day long plantation event, a total of 16 CFUG members were involved, including four women. The members also discussed on ways to protect the plantation sites from grazing and fire. As a decision, grazing was banned, while road/trails around the plantation sites were considered as fire lines. Besides, the CFUG members were involved during the plot establihsment, selection of trees, and harvesting, which ensured that they could continue the work in the future as well.

Apart from the engagement with CFUG members, the process of establishing demonstration plots involved the DFO in order to obtain harvesting permits. Moreover, series of discussions with the concerned stakeholders including the DFO and FECOFUN were held to seek their views. Prior to preparing the Memorandom of Understanding with the CFUG, a rapid silvicultural appraisal was carried out in order to have a better understanding of the type of species in the forest. Following the establishment of demonstration plots, a management plan was prepared incorporating the details of harvesting within the plots, which was later endorsed by the general assembly of Lampata CFUG. The tree felling was carried out following the permission from the DFO. Besides, visit from the Department of Forests, including the Director General (DG) and DFO was organized, which was primarily aimed at seeking on-site feedback for enhancing the effectiveness of the demonstration plots.

\section{Kalopani CFUG, Kavre}

Kalopani CFUG in Dhungkharka has 175 ha of naturally regenerated Thingre pine (Abies pindrow) and Khasru forest (Quercus semicarmifolia). The Pine forest is 20 years old and really dense (1300 poles/ha). It needs a heavy thinning, but there is no such provision in the OP and therefore DFO did not provide permit. It has seriously hampered growth of the poles. Similarly, a considerable area of the Khasru forest, a key source of fodder to contribute to the dairy enterprise, is heavily infected by Mistletoe parasite and is gradually killing trees.

After initial discussion with the EC and the Assistant Forest Officer of the area, different plots were established as a step on silviculture management, where one plot was established in the mature stand to demonstrate Shelterwood system, and two plots were established in the young stand to demonstrate selection silviculture. Plots with size of $60 \mathrm{~m} \times 70 \mathrm{~m}$ with a total area of 0.42 ha were established for Thingre salla. Likewise, 40 trees were selected in order to demonstrate silviculture options for Khasru.

The EnLiFT team members held meetings with the CFUG EC and other members to mainly discuss on the establishing demonstration plots in Kalopani. The plots were mainly targeted for Khasru and Thingure Salla management and three different types of treatments were applied. As a result, the Kalopani CFUG members opted for its management by establishing demonstration plots. Most importantly, the CFUG members were involved right from the initial phase of plot establishment, selection of the mother trees, harvesting techniques among others.

In addition to the support, the EnLiFT team organized a visit of the DG of DoF to Kalopani $\mathrm{CF}$ which provided a type of confidence among the CFUG members to carry out silviculture intervention in their forest. Moreover, people had a sense of fear when it came to felling trees, however following the visit of the DG, the misconception that felling of trees is not always illegal as long it is under the OP has been established.

\section{Dharapani CFUG, Kavre}

Dharapani CFUG in Bhumlu Gaupalika has 40 ha of plantation pine forest (Pinue patula). It is already 35 years old, reached to its rotation cycle. Unfortunately, the forest management has been limited to removal of $4 \mathrm{D}$ trees. The CGUG is weakened due to its poor internal governance, embezzlement and is suffering from a legal case at CIAA. Last time, it could not get DFO permit to sell its harvest and lost about $950 \mathrm{cft}$ of timber due to fire. This has been an unfortunate group which has been unable to benefit its good and mature forest stock.

The case of Dharapani is another illustration of how technical and institutional aspects should be integrated for silvicultural intervention. Realizing the need for proper forest management around Chaubas area, a visit of DG of DoF was organized by the EnLiFT project. The visit team had an impression that there is a need 
for silvicultural intervention in the forests of Chaubas including Dharapani CF. Following this, a training programme was organized by the DFO. Kavre along with EnLiFT project, where CFUG members of Dharapani were invited along with other user groups in the region. Shelterwood system was demontrated in Chapani CF. Citing the relevance of the treatment in their forest, CFUG members of Dharapani expressed their interest in carrying out the intervention to the EnLiFT project. The time was perfect in the sense that the OP of Dharapani had expired and there was a space to incorporate the silviculture management aspect in the document. The EC called for a meeting and decided to incorporate silviculture management in Dharapani CF, which was later endorsed by their general assembly.

The CFUG members were involved during the selection of mother trees in addition to applying harvesting techniques. The members were previously applying negative thinning, which did not properly follow the guideline. However, following the introduction of shelterwood system, the user groups are optimistic on growth of the trees. With the onsite training provided by the EnLiFT, the user group members are now capable to apply the treatments in the future.

\section{Key issues and lessons}

As described above, our action research in Kavre and Lamjung tried to develop a silvo-institutional model that integrates technical measurement and assessment with institutional process towards effective and sustainable outcomes of silviculturebased forest management. As presented in table 1, it includes four major elements:

- First, creating a supportive institutional environment at all levels through formal and informal engagement with range of actors beyond forest officials and CF members. This provides a secure working environment and increases the confidence of the officials and $\mathrm{CF}$ leaders.

- Second, measurement, assessment and planning that involve science and civic perspectives. Unlike the dominant practice, where technicians carry our technical assessment, prepare plan and share with CF members, we integrate these rather technical measurement and assessment with civic participation and consent. This is not only to inform the people about science, but at the same time, the assessment and plans being influenced by indigenous and local knowledge, practice and priorities.

- $\quad$ Third element - endorsement and approval is to align technical assessment and plans with administrative, legal and institutional practice for their refinement, legitimacy and authenticity.

- Fourth, action and constant monitoring is because, we take the silviculture science not as static end product, instead a moving, dynamic science which has rooms for improvement and refinement.

The experimentation with SIM in Kavre and Lamjug have shown a promising early success not only in garnering local support, stakeholder support, assurance to the forest officials, but also getting the technology right, relevant to local needs and aspiration. SIM also works by building capacity of forest technicians and CF leaders. The rigorous process of decision, measurement, assessment, planning and implementation help develop both technical and institutional capacity of the relevant actors.

The experimentation with the SIM is on-going. We continue to monitor, measure and document the biophysical (regeneration, growth, viability of the stock, fire, grazing, wind) and institutional (CFUG governance, management of increased funds, distributional arrangement, stakeholder responses, future planning of CFUG) responses. As these processes are conducted locally with a low cost, we do not foresee major challenges in terms of replication. Of course, there is a need of better appreciation of the Model by the forest officials, FECOFUN and other support agencies. In fact, some of these new practices have been replicated by the neighbouring CFUGs on their own. Examples include: one CFUG in Methinkot, three CFUGs in Dhungkharka and two CFUGs in Tandrang-taxar have used these technologies in management and harvesting their forests. The sustainable forest management practices can be scaled out by putting a clear incentive structure within the Department of Forest. For example, if we link DFO's achievement in implementing forest management with his/her periodic performance review that would encourage them to actively implement it in the field. Reforms in all concerned agencies like government institutions, forest user groups and other service 
providers are vital to bring a national momentum on silviculture-based forest management.

The SIM option we have presented can help overcome unproductive polarisation of forest management approach among various lines. Anew wave of intensive forest management initiatives including a 'scientific forestry' have been piloted and expanded in various part of the country. As these initiatives are in their early stages, they must be carefully monitored, documented and lessons should be drawn. We should be careful for not to be a die-hard fan of any particular approach and instead be open, reflective and prepare to reform and revise. Underpinning SIM is an adaptive learning approach that integrates scientific, technological aspects with civic consent. This approach is helpful to learn from past and current initiatives and tackle ongoing challenges to develop and promote silvicultural innovations towards productive, sustainable and equitable forest management in Nepal not only in $\mathrm{CF}$ but across the national forests.

It is notable that the SIM described in figure 1 does not include elements of equitable benefit sharing. This is because most CFUGs have existing equitable sharing of resource and benefits arrangement governed by existing forestry rules and laws. We have observed that from the first cycle of SIM in our research sites that the increase of timber and product flows from the community forests resulting from silviculture-based management satisfied the forest users' demand particularly the poor and disadvantaged groups. Additionally, the cash flows of CFUGs have been increased resulting from sales of timber from relatively smaller forest areas boosting CFUG's financial position.

\section{Conclusion}

This paper has introduced the silvo-institutional model, as it was practiced in Kavre and Lamjung in few research sites. Informed by the past failures and recognising the continuing challenges of intensive forest management in the project areas, we piloted an approach to promote active and equitable forest management, which we now call SIM. We considered four key elements in the SIM: creating favourable institutional environment; integrating science and civic consent during measurement, assessment and planning; scrutinise and legitimise the planning process through endorsement and approval processes; and action and continuous monitoring, documentation and reflection. While SIM may appear to be costly and time-consuming, all but the silviculture demonstration plots establishment are part of usual operation plan revisions and implementation process. What makes SIM different is bringing up the need for silviculturebased forest management at the front and centre of existing CFUG operations and activities.

The initial result shows that a thorough and integrated approach to technical and institutional process, which underpinned SIM has led to a good silvicultural-based forest management in action research areas. Though these are very small and specific cases, these processes do not involve huge transaction cost and can be scaled out elsewhere. This means adopting a genuinely engaging process that brings scientific process into public scrutiny and community consent with proper documentation and periodic reflective learning amongst stakeholders that feeds into the policy process and help achieve sustainable forest management objectives.

This research further points to the fact that more works need to be done to explore and identify SIM pathways that can work best for the poor and disadvantaged groups in the community. What is also needed is to test SIM tools that can work for various forest products and services which are marketable and have the potential to raise incomes to the unemployed rural youths.

\section{Acknowledgements}

This paper is a product of a five-year action research project entitled, Enhancing Livelihoods and Food security from Agroforestry and Community Forestry in Nepal (EnLiFT), funded by the Australian Centre for International Agriculture Research (ACIAR).

\section{References}

Banjade, M., Paudel, N. S., Karki, R., Sunam, R. and Paudyal, B. 2011. Putting timber into the hot seat: discourse, policy and contestations over timber in Nepal. Discussion Paper Series 11: 2. Forest Action, Kathmandu, Nepal. 16 p.

Banjade, M. R. 2006. Transforming policies and institutions in community forestry of Nepal: The role of participatory action 
research. Exploring Regional CBNRM Policy and Policy Advocacy, International Institute of Rural Reconstruction (IIRR), the Philippines.

Cedamon, E., Nuberg, I., Paudel, G., Basyal, M., Shrestha, K. and Paudel, N. S. 2016. Rapid silviculture appraisal to characterise stand and determine silviculture priorities of community forests in Nepal. Small-Scale Forestry. DOI 10.1007/s11842-016-9351-0

Chhetri, B. B. K., Lund, J. F. and Nielsen, O. J. 2012. The public finance potential of community forestry in Nepal. Ecological Economics 73: 113-121.

Hill, I. 1999. Forest Management in Nepal: Economics and Ecology. World Bank Technical Paper No. 445. The World Bank, Washington, D. C., USA. 50p.

Hurtig, E. 1998. The Nepali language report on the consultative process on Bara Forest Management. A memo from Embassy of Finland, Kathmandu. Memo no. 1122; 8 Dec 1998.

King, G. C., Hobley, M. and Gilmour, D. A. 1990. Management of forests for local use in the hills of Nepal: towards the development of participatory forest management. Journal of World Forest Resource Management 5 (1): $1-13$.

McDougall, C., Ojha, H., Pandey, R. K., Banjade, M. R. and Pandit, B. H. 2007. Enhancing adaptiveness and collaboration in community forestry in Nepal: reflections from participatory action research. Adaptive Collaborative Management of Community Forests in Asia, 52.

Ojha, H. R., Paudel, N. S. Banjade, M. R., McDougall, C. and Cameron, J. 2010. The deliberative scientist: integrating science and politics in forest resource governance in Nepal. In Beyond the Biophysical: Knowledge, Culture, and Politics in Agriculture and Natural Resource Management (eds.) German, L. Ramisch, J. J. and Verma, R. Dordrecht, Hiedelberg, London and New York, Springer, 167-191.
Paudel, N. S., Paudel, G., Karki, R. and Khatri, D. B. 2014. Revenue and employment opportunities from timber management in Nepal's community forests. Policy Brief No. 29, Forest Action, Kathmandu, Nepal.

Springate-Baginski, O., Dev, O. P., Yadav, N. P. and Soussan, J. 2003. Community forest management in the Middle Hills of Nepal: the changing context. Journal of Forest and Livelihood 3 (1): 5-20.

Subedi, B. P., Ghimire, P. L., Koontz, A., Khanal, S. C., Katwal, P., Sthapit, K. R. and S. Khadka M. 2014. Private Sector Involvement and Investment in Nepal's Forestry: Status, Prospects and Ways Forward. Study Report. Multi Stakeholder Forestry Programme - Services Support Unit, Babarmahal, Kathmandu, Nepal.

Subedi, V. R. 2012. Forest management: opportunities and challenges in Nepal (in Nepali). Hamro Ban Sampada 10 (1): 61-68.

Thoms, C. 2008. Community control of resources and the challenge of improving local livelihoods: a critical examination of community forestry in Nepal. Geoforum 39: 1452-1465.

Yadav, B. D., Bigsby, H. and Macdonald, I. 2008. "Who are controlling community forestry user groups in Nepal? Scrutiny of elite theory". Paper presented at the New Zealand Agricultural and Resource Economics Society Conference, August 28-19, 2008. Nelson, New Zealand.

Yadav, N. P., Yadav, K. P., Yadav, K. K. and Thapa, N. 2009. Facilitating the transition from passive to active community forest management: lessons from Rapti Zone, Nepal. Journal of Forest and Livelihood 8 (2): 51-66. 